\title{
Validasi Algoritma Estimasi konsentrasi Klorofil-a dan Padatan Tersuspensi Menggunakan Citra Terra dan Aqua Modis dengan Data In situ (Studi Kasus: Perairan Selat Makassar)
}

\author{
Endang Prinina ${ }^{1}$, Lalu Muhamad Jaelani ${ }^{1}$, Salam Tarigan ${ }^{2}$ \\ ${ }^{1}$ Teknik Geomatika, Fakultas Teknik Sipil dan Perencanaan, Institut Teknologi Sepuluh Nopember (ITS) \\ Jl. Arief Rahman Hakim, Surabaya 60111 Indonesia \\ e-mail:1mjaelani@geodesy.its.ac.id \\ ${ }^{2}$ Laboratorium Penginderaan Jauh, Pusat Penelitian Oceanografi, Lembaga Ilmu Pengetahuan Indonesia \\ Jl. Pasir Putih No.1, Ancol Timur, Jakarta Utara 14430
}

\begin{abstract}
Abstrak-Klorofil-a dan Padatan Tersuspensi (TSS) merupakan parameter fisik kualitas perairan. Pigmen klorofil-a memiliki daya serap yang tinggi pada gelombang tampak biru dan merah. TSS merupakan zat padatan sedimentasi dari aliran sungai yang membawa material-material organik maupun anorganik. Kandungan TSS yang tinggi sangat mengganggu proses fotosintesis pada fitoplankton yang merupakan produsen penghasil zat klorofil-a. Sehingga TSS juga mampu menyerap gelombang tampak. Kemampuan klorofil-a dan TSS dalam menyerap gelombang tampak dapat di amati dengan menggunakan teknologi penginderaan jauh. Pemanfaatan teknologi ini membutuhkan algoritma dalam menentukan nilai estimasi konsentrasi klorofil-a dan TSS. Penelitian ini menggunakan citra Terra dan Aqua MODIS. Penelitian ini bertujuan untuk memvalidasi hasil algoritma klorofil-a dan TSS yang telah ada dalam perangkat lunak SeaDAS 7.3.1. Dari hasil penelitian ini didapatkan koreksi atmosfer terbaik dalam pendugaan klorofil-a dan TSS yaitu koreksi atmosfer MUMM. Dari hasil pemetaan klorofil-a dan TSS menghasilkan nilai NMAE sebesar $158,34 \%$ dan $65,28 \%$. Hal ini menunjukkan bahwa algoritma empiris ini tidak dapat diterapkan pada Selat Makassar. Sebaran klorofil-a terendah sebesar 0,105 $\mu \mathrm{g} / \mathrm{l}$ dan tertinggi sebesar $0,783 \mu \mathrm{g} / \mathrm{l}$ pada citra Terra MODIS. Sedangkan sebaran TSS terendah $0,02 \mathrm{mg} / \mathrm{l}$ dan tertinggi $6,88 \mathrm{mg} / \mathrm{l}$ pada citra Terra MODIS. Citra Terra MODIS lebih baik dalam pendugaan klorofil-a dan TSS dengan menggunakan algoritma empiris di SeaDAS 7.3.1 daripada menggunakan citra Aqua MODIS.
\end{abstract}

Kata Kunci-Algoritma, Klorofil-a, TSS, Validasi.

\section{PENDAHULUAN}

$\mathrm{S}$ ELAT Makassar merupakan salah satu bagian dari samudra dalam, dimana massa air laut bergerak dari Samudra Pasifik Utara ke Samudra Hindia. Pertukaran massa air dari Samudra Pasifik menuju Samudra Hindia melalui Laut Sulawesi, Laut Flores dan Laut Jawa yang mempengaruhi tingkat produktivitas primer di perairan Selat Makassar [1]. Produktivitas primer ditunjukkan dengan adanya fitoplankton yang dapat menghasilkan klorofil-a [2]. Konsentrasi klorofil-a merupakan parameter kunci dalam pengujian kualitas air [3]. Parameter fisik lainnya yaitu padatan tersuspensi yang biasa dikenal dengan istilah Total Suspended Solid (TSS). Nilai sebaran klorofil-a dan TSS di perairan dapat diketahui melalui pengukuran in situ dan ex situ. Pengukuran in situ yaitu dengan pengambilan sampel langsung ke lapangan. Sedangkan pengukuran ex situ yaitu dengan analisis citra menggunakan teknologi penginderaan jauh. Analisis citra untuk klorofil-a dan TSS dapat dilakukan dengan menggunakan perangkat lunak pengolah citra.

Dalam melakukan analisis citra untuk estimasi konsentrasi klorofil-a dan TSS diperlukan suatu algoritma yang sesuai untuk perairan Selat Makassar. Estimasi parameter kualitas air (klorofil-a dan TSS) dari data penginderaan jauh umumnya tergantung pada keakuratan koreksi atmosfer dan model yang menghubungkan antara data reflektan penginderaan jauh dengan parameter kualitas air yang akan diekstrak [4]. Hal ini dikarenakan perairan Indonesia memiliki karakteristik yang berbeda-beda sehingga tidak semua algoritma dapat sesuai untuk analisis konsentrasi klorofil-a dan TSS. Perumusan masalah utama dalam penelitian ini yaitu untuk memvalidasi hasil algoritma klorofil-a dan TSS dengan 3 koreksi atmosfer yang berbeda di perairan Selat Makassar serta pengaruh koreksi atmosfer yang sesuai terhadap algoritma klorofil-a dan TSS.

\section{METODE PENELITIAN}

\section{A. Lokasi Penelitian}

Lokasi penelitian di perairan Selat Makassar dengan dibatasi oleh koordinat $2^{\circ} 53^{\prime} 3,14^{\prime \prime}$ LU - $1^{\circ} 23^{\prime} 3,14^{\prime \prime}$ LS dan $116^{\circ} 53^{\prime}$ ' $39,15^{\prime \prime}$ BT $-122^{\circ} 13^{\prime} 20,95^{\prime \prime}$ BT. Selat ini berada diantara pulau Kalimantan dan Sulawesi yang menghubungkan Samudra Pasifik dengan Samudra Hindia. Berikut gambaran lokasi penelitian ini. 


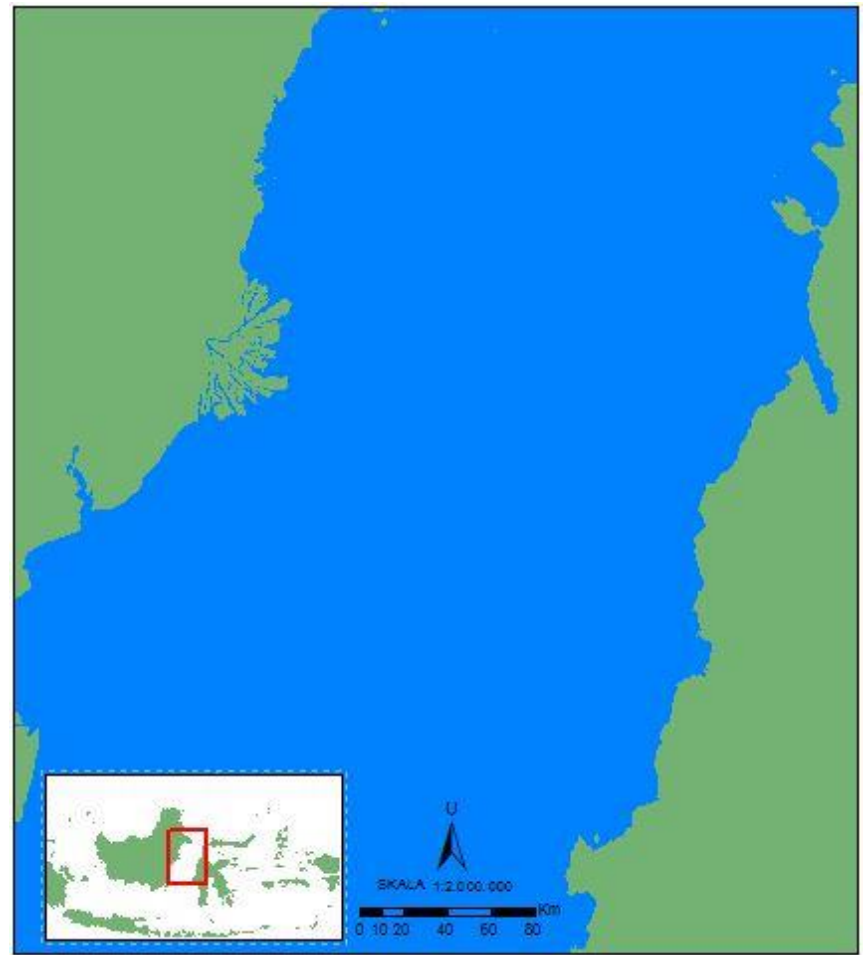

Gambar. 1. Lokasi Penelitian [5]

\section{B. Data dan Peralatan}

Data yang digunakan dalam penelitian ini yaitu citra satelit Terra dan Aqua MODIS level 1B lokasi perairan Selat Makassar serta data survei lapangan dari Ekspedisi Widya Nusantara (EWIN) 2013 yang dilakukan oleh Pusat Penelitian Oceanografi-LIPI. Survei lapangan menggunakan kapal riset KR. Baruna Jaya VIII. Sedangkan pengolahan data citra menggunakan perangkat lunak SeaDAS 7.3.1.

\section{Metode Penelitian}

Citra Terra dan Aqua MODIS yang telah diunduh melalui website [5] tahap pertama dilakukan proses georeferensi. Hal ini bertujuan menyesuaikan citra dengan keadaan sebenarnya di Bumi. Citra yang telah memiliki koordinat dipotong sesuai dengan area yang akan diteliti.

Selanjutnya dilakukan koreksi atmosfer dengan menerapkan tiga algoritma koreksi atmosfer yaitu GW 94, GWI, dan MUMM yang telah tersedia pada perangkat lunak SeaDAS 7.3.1 dengan tujuan untuk diaplikasikan pada pengamatan akurasi warna lautan dalam mendapatkan kembali water leaving radiance pada tingkat lautan dari total radian yang terekam pada atmosfer [6].

Citra yang telah terkoreksi atmosfer diterapkan algoritma klorofil-a dan TSS pada citra Terra dan Aqua MODIS. Dengan menggunakan persamaan di bawah ini.

$$
\begin{aligned}
& X=\log 10\left(\frac{\operatorname{Rrs}\left(\lambda_{1}\right)}{\operatorname{Rrs}\left(\lambda_{2}\right)}\right) \\
& C h l-a=10^{\left(a_{0}+a_{1}+\left(a_{2} \cdot X^{2}\right)+\left(a_{3} \cdot X^{3}\right)+\left(a_{4} \cdot X^{4}\right)\right)}
\end{aligned}
$$

Koefisien :

$\operatorname{Rrs}\left(\lambda_{1}\right)=\operatorname{Rrs}$ pada kanal biru $(488 \mathrm{~nm})$
$\operatorname{Rrs}\left(\lambda_{2}\right)=$ Rrs pada kanal hijau $(531 \mathrm{~nm})$

$a_{0}=0,3272$

$a_{1}=-2,9940$

$a_{2}=2,7218$

$a_{3}=-1,2259$

$a_{4}=-0,5683$

Dalam estimasi konsentrasi klorofil-a menggunakan algoritma OC4. Sedangkan dalam mengestimasi konsentrasi TSS menggunakan algoritma TSM Swim. Adapun algoritma TSS adalah sebagai berikut:

$\operatorname{TSM}\left(\frac{m g}{L}\right)=10^{\left(a_{0}+X *\left(a_{1}+X *\left(a_{2}+X * a_{3}+X *\left(a_{4}+X * a_{5}\right)\right)\right)\right.}$

$X=\log 10\left(\frac{n L w[1]+n L w[2]}{n L w[4]}\right)$

Keterangan :

$n L w=$ Normal Water Leaving Radiance

$n L w[1]=n L w 412 \mathrm{~nm}$

$n L w[2]=n L w 443 \mathrm{~nm}$

$n L w[4]=n L w 488 \mathrm{~nm}$

$a_{0}=0,490330$

$a_{1}=-2,712882$

$a_{2}=3,412666$

$a_{3}=8,336478$

$a_{4}=12,111023$

$a_{5}=-5,961926$

Dalam memvalidasi data hasil pengolahan citra dengan data in situ menggunakan uji statistika NMAE dan RMSE. Data yang divalidasi dengan NMAE minimal bernilai $\leq 30 \%$. Berikut ini persamaan NMAE dan RMSE.

$$
\begin{aligned}
& \operatorname{NMAE}(\%)=\frac{1}{N} \sum_{i=1}^{N}\left|\frac{x_{\text {est } i, i}-x_{\text {meas }, i}}{x_{\text {meas }, i}}\right| 100 \\
& R M S E=\sqrt{\frac{\sum_{i=1}^{N}\left(x_{\text {est } i, i}-x_{\text {meas }, ~}\right)^{2}}{N}}
\end{aligned}
$$

Dimana $x_{e s t i, i}$ dan $x_{\text {meas }, i}$ adalah nilai estimasi dan nilai pengukuran. Sedangkan N adalah jumah data yang digunakan. Data hasil pengolahan citra didapatkan dengan mengekstrak nilai-nilai klorofil-a dan TSS pada masing-masing citra. Pada penelitian ini digunakan 15 stasiun pada citra Terra MODIS dan 4 stasiun pada citra Aqua MODIS untuk divalidasi dengan data in situ. Perbedaan jumlah stasiun dalam memvalidasi dengan data in situ dikarenakan perbedaan kondisi citra satelit yang memiliki awan pekat pada citra Aqua MODIS dibandingkan dengan citra Terra MODIS.

Koreksi geometrik dilakukan dengan meletakkan 10 titik GCP sebagai acuan berdasarkan peta vektor dengan skala 1:1.000.000. Koreksi geometrik memenuhi toleransi apabila didapatkan RMS Error yang nilainya $\leq 1$ piksel.

Hasil dari penelitian ini yaitu peta sebaran klorofil-a dan TSS dengan 3 koreksi atmosfer yang berbeda, baik pada citra Terra maupun Aqua MODIS di perairan Selat Makassar. Pada tahap akhir penelitian ini yaitu peta sebaran konsentrasi klorofil-a dan TSS di Perairan Selat Makassar dengan koreksi atmosfer GW 94, GWI dan MUMM. 


\section{HASIL}

\section{A. Hasil Reprojection (Reproyeksi)}

Proses reprojection dilakukan dengan memasukkan sistem proyeksi, dalam hal ini sistem proyeksi yang digunakan adalah WGS 84 dengan sistem koordinat geografis Lat/Lon. Berikut adalah hasil reporjection citra MODIS (Gambar 2).

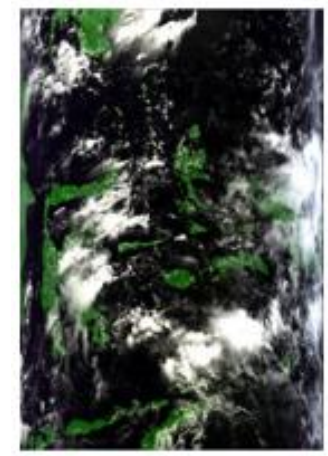

(a)

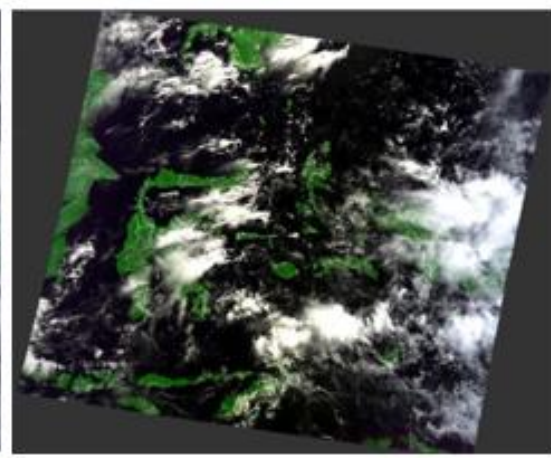

(b)
Gambar. 2. (a) citra sebelum direproyeksi, (b) citra setelah direproyeksi

\section{B. Hasil Koreksi Geometrik}

Citra satelit Terra dan Aqua MODIS dengan resolusi spasial 1 kilometer dikoreksi menggunakan peta vektor Indonesia sebagai acuan. Hasil koreksi geometrik pada citra Terra dan Aqua MODIS adalah sebagai berikut:

Tabel 1.

Nilai RMS Error pada Citra MODIS

\begin{tabular}{ccc}
\hline \hline \multirow{2}{*}{ Citra } & Akuisisi Citra & RMS Error (Piksel) \\
\hline \multirow{2}{*}{ Terra } & 10 Juni 2013 & 0,16636 \\
& 15 Juni 2013 & 0,02754 \\
\multirow{2}{*}{ Aqua } & 16 Juni 2013 & 0,03458 \\
& 11 Juni 2013 & 0,04786 \\
\hline \hline
\end{tabular}

Dari tabel diatas dapat dilihat bahwa hasil RMS Error $\leq 1$ piksel, sehingga hasil koreksi geometrik yang telah dilakukan memenuhi batas toleransi.

\section{Validasi Nilai Estimasi dengan Data In situ}

Proses validasi dalam penelitian ini menggunakan data in situ Selat Makassar. Terdapat 20 titik data in situ yang digunakan untuk proses validasi. Tetapi hanya 15 stasiun yang digunakan pada citra Terra dan 4 stasiun pada citra Aqua MODIS. Proses validasi ini dilakukan dengan cara membandingkan nilai klorofil-a maupun TSS terhadap data in situ. Dalam hal ini, hasil pengukuran data in situ dijadikan acuan. Adapun validasi dan korelasi masing-masing algoritma terhadap data in situ adalah sebagai berikut.
D. Validasi Perhitungan Klorofil-a pada Citra Terra MODIS dengan Data In situ.

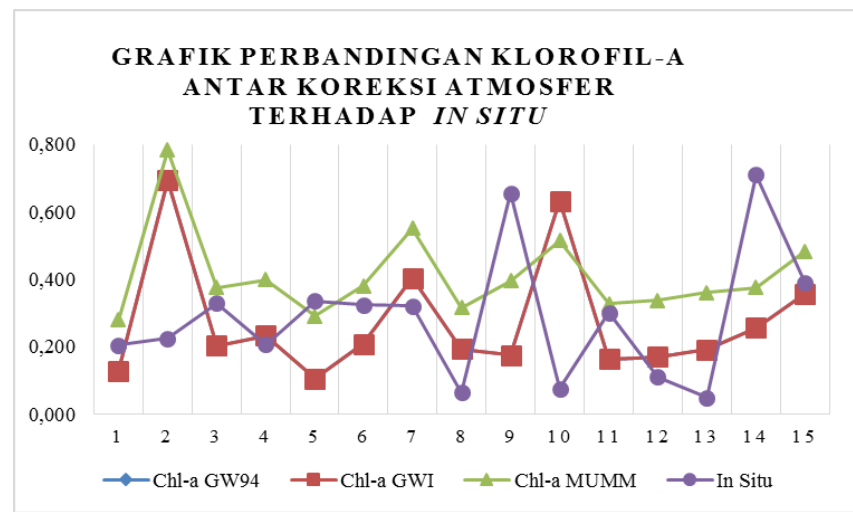

Gambar. 3. Grafik Hubungan 3 Algoritma Klorofil-a terhadap Data in situ pada Citra Terra MODIS

Nilai klorofil-a dengan koreksi atmosfer GW 94 dan GWI memiliki nilai yang saling berimpit. Sedangkan nilai klorofil-a dengan koreksi atmosfer MUMM yang seragam dengan GW 94 maupun GWI tetapi berbeda jauh dengan nilai konsentrasi klorofil-a data in situ. Hubungan nilai estimasi dan data in situ klorofil-a dapat ditunjukkan dengan besarnya nilai RMSE dan NMAE.

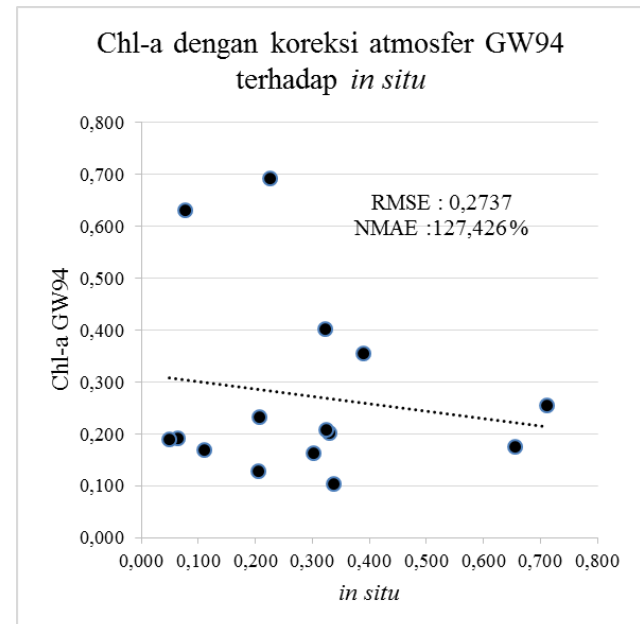

Gambar. 4. Grafik Korelasi antara Klorofil-a GW94 dengan Data in situ pada citra Terra MODIS.

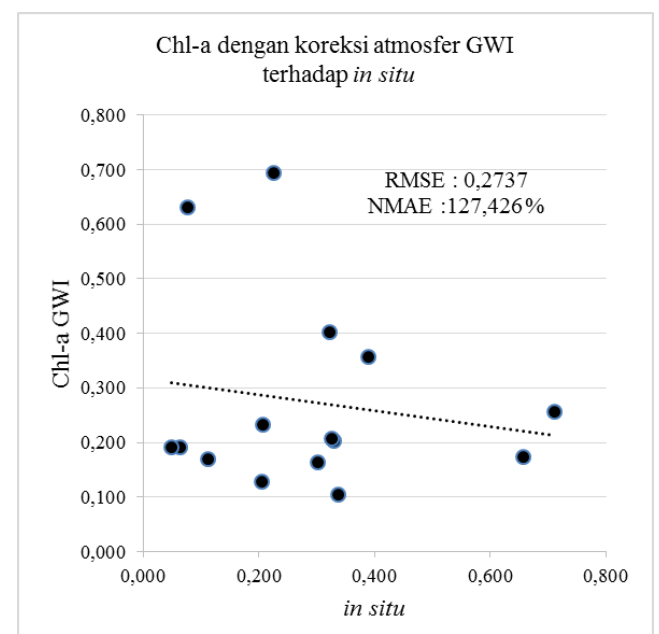

Gambar. 5. Grafik korelasi antara klorofil-a GWI dengan Data in situ pada citra Terra MODIS 


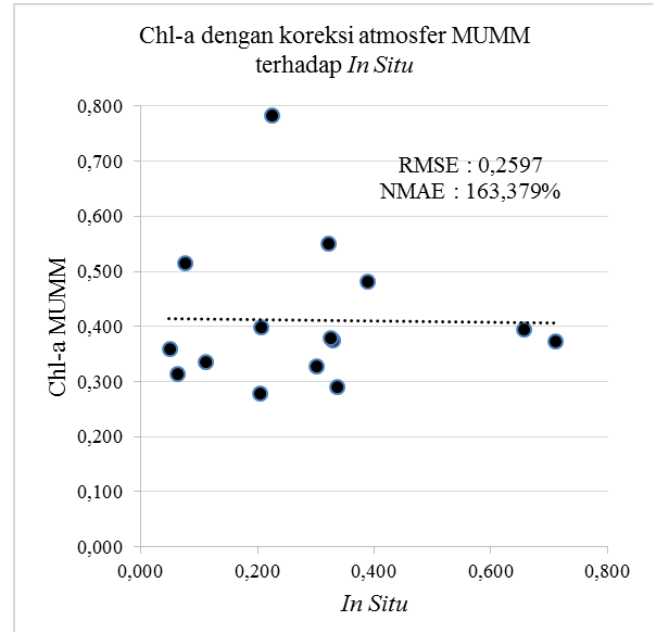

Gambar. 6. Grafik Korelasi antara Klorofil-a MUMM dengan Data in situ pada citra Terra MODIS.

Berdasarkan korelasi tersebut menunjukkan bahwa koreksi atmosfer MUMM lebih baik dalam pendugaan klorofil-a walaupun tidak memenuhi syarat minimum NMAE.

E. Validasi Perhitungan Klorofil-a pada Citra Aqua MODIS dengan Data In situ.

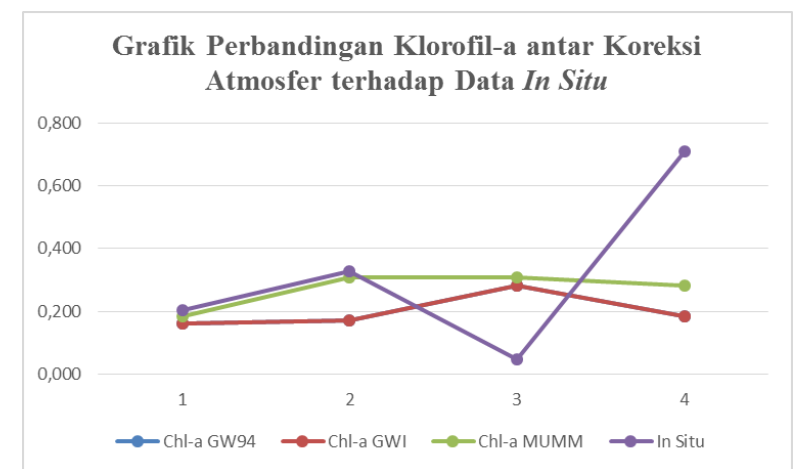

Gambar. 7. Grafik Hubungan 3 Algoritma Klorofil-a terhadap Data In situ pada Citra Aqua MODIS.

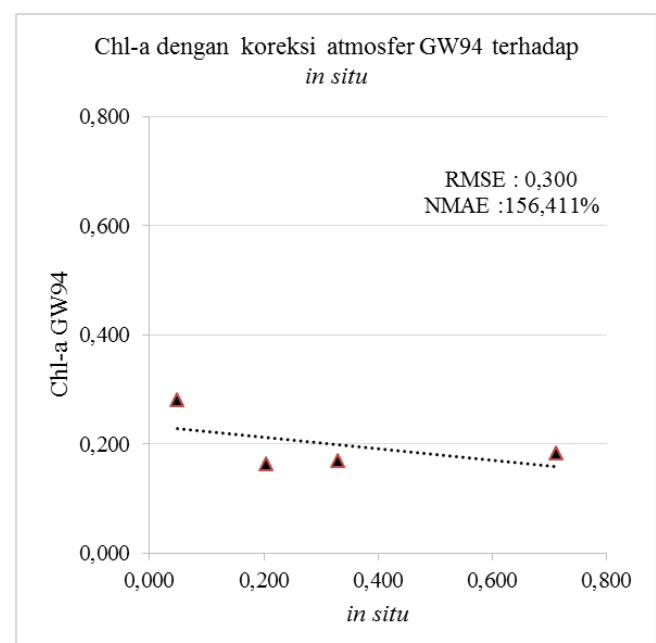

Gambar. 8. Grafik Korelasi antara Klorofil-a GW94 dengan Data In situ pada Citra Aqua MODIS.

Seperti halnya pada citra Terra MODIS, nilai klorofil-a dengan koreksi atmosfer GW 94 dan GWI memiliki nilai yang saling berimpit. Sedangkan nilai klorofil-a dengan koreksi atmosfer MUMM yang seragam dengan GW 94 maupun GWI tetapi berbeda jauh dengan nilai klorofil-a data in situ. hubungan nilai estimasi dan data in situ dapat ditunjukkan dengan besarnya nilai RMSE dan NMAE berikut ini.

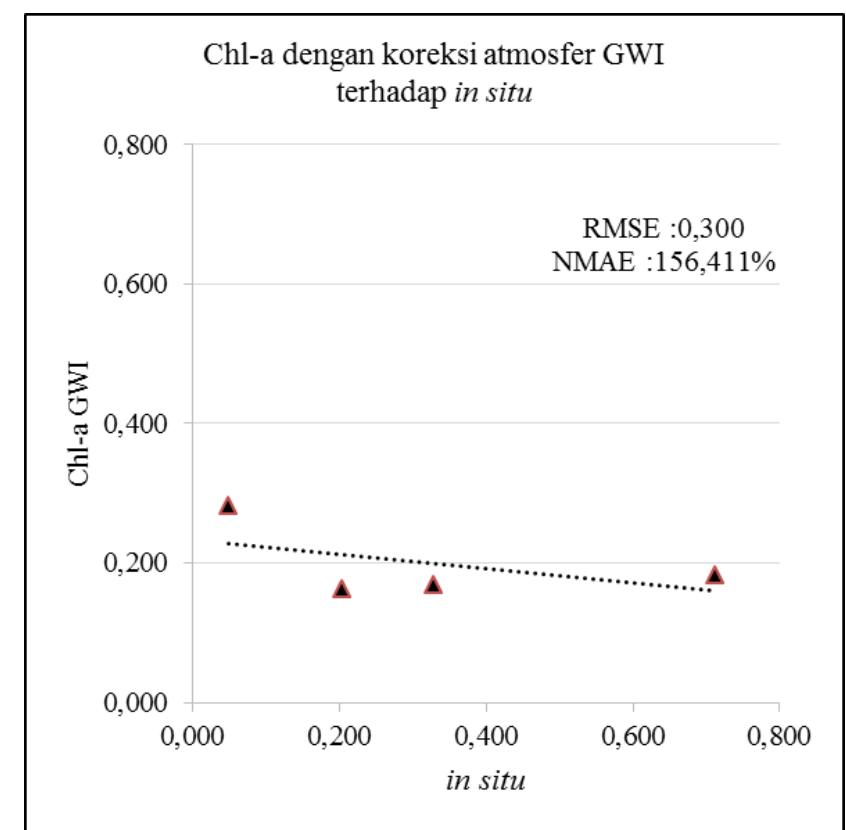

Gambar. 9. Grafik Korelasi antara Klorofil-a GWI dengan Data In situ pada citra Aqua MODIS.

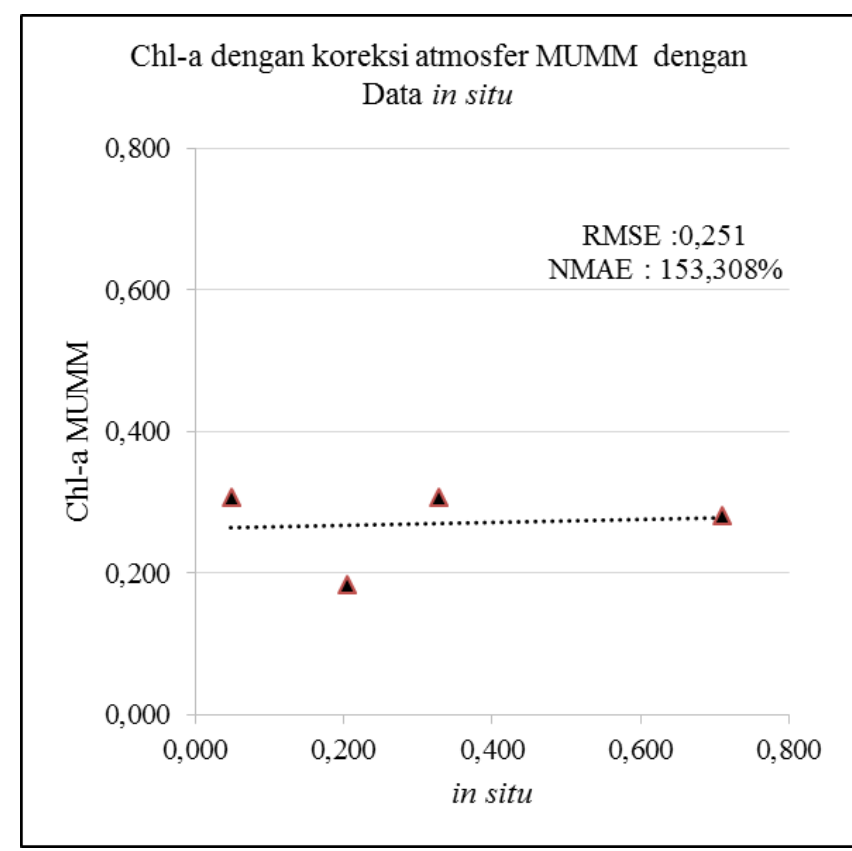

Gambar. 10. Grafik Korelasi antara Klorofil-a MUMM dengan Data In situ pada citra Aqua MODIS.

Berdasarkan korelasi tersebut menunjukkan bahwa koreksi atmosfer MUMM lebih baik dalam pendugaan klorofil-a walaupun tidak memenuhi syarat minimum dari NMAE. Dari hasil penelitian ini didapatkan bahwa koreksi atmosfer MUMM cocok digunakan dalam mengestimasi konsentrasi klorofil-a pada perairan Selat Makassar. 
F. Validasi Perhitungan TSS pada Citra Terra MODIS dengan Data In situ.

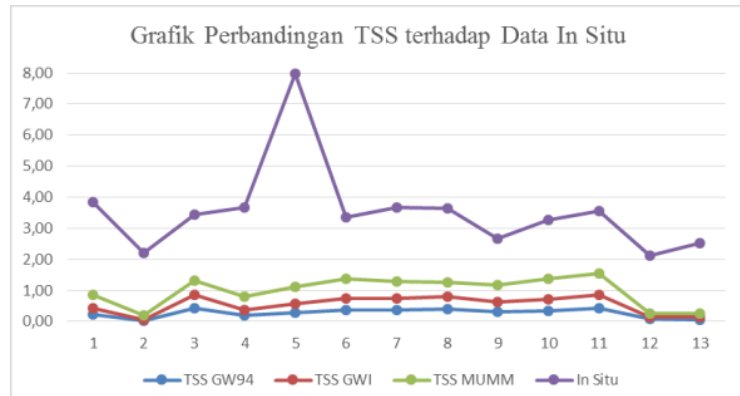

Gambar. 11. Grafik Hubungan 3 Algoritma TSS terhadap Data in situ pada Citra Terra Modis

Berdasarkan grafik diatas menunjukkan bahwa nilai TSS dengan 3 koreksi atmosfer GW94, GWI, dan MUMM memiliki nilai yang hampir sama. Tetapi berbeda jauh dengan nilai TSS data in situ. hal ini didukung dengan nilai NMAE antara estimasi TSS dengan data in situ.

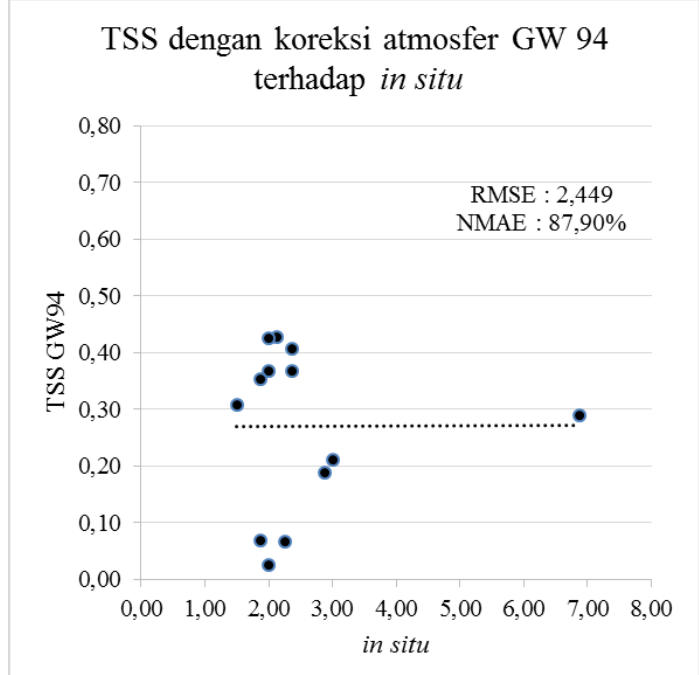

Gambar. 12. Grafik Korelasi antara TSS GW 94 dengan Data In situ pada Citra Terra MODIS.

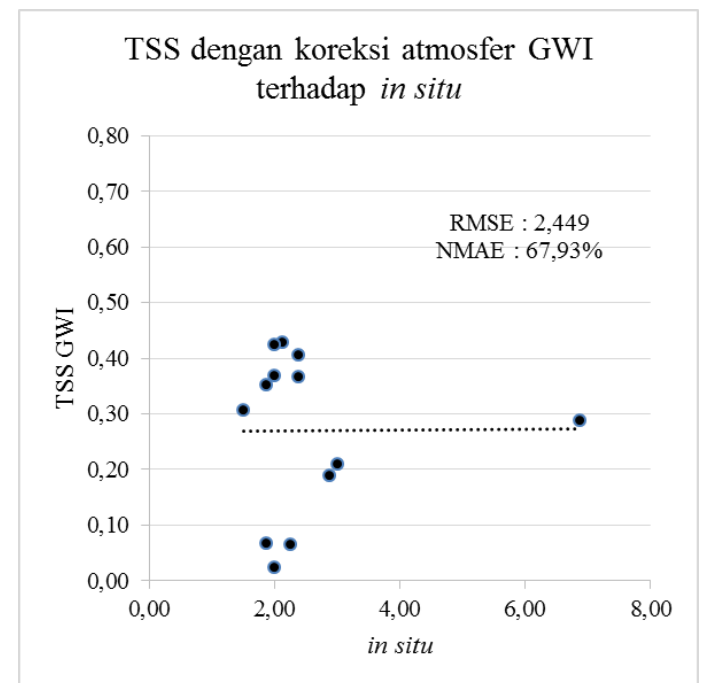

Gambar. 13. Grafik Korelasi antara TSS GWI dengan Data In situ pada Citra Terra MODIS.

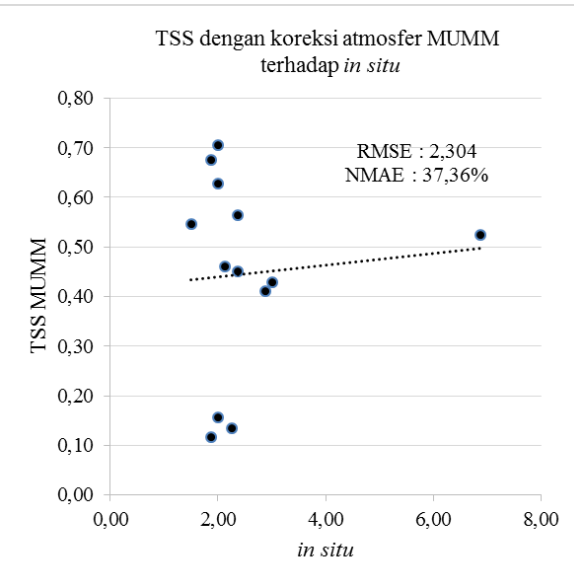

Gambar. 14. Grafik korelasi antara TSS MUMM dengan Data in situ pada citra Terra MODIS.

Berdasarkan nilai NMAE dan RMSE didapatkan koreksi atmosfer MUMM lebih baik daripada yang lain untuk mengestimasi TSS, tetapi tidak dapat direkomendasikan karena nilai NMAE tidak memenuhi syarat minimal NMAE.

\section{G. Validasi Perhitungan TSS pada Citra Aqua MODIS dengan Data In situ.}

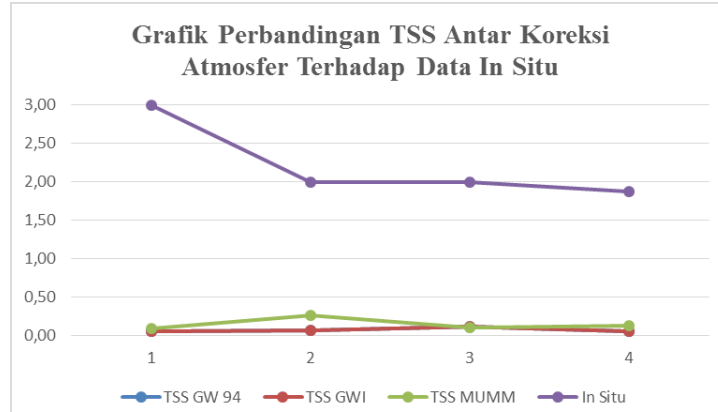

Gambar. 15. Grafik Hubungan 3 Algoritma TSS terhadap Data in situ pada Citra Aqua MODIS.

Berdasarkan grafik diatas menunjukkan bahwa nilai TSS dengan 3 koreksi atmosfer GW94, GWI, dan MUMM memiliki nilai yang hampir sama. Tetapi berbeda jauh dengan nilai TSS data in situ. Hal ini didukung dengan nilai NMAE antara estimasi TSS dengan data in situ. Serta validasi ini tidak dapat dijadikan acuan karena hanya menggunakan 4 stasiun untuk memvalidasi dengan data in situ.

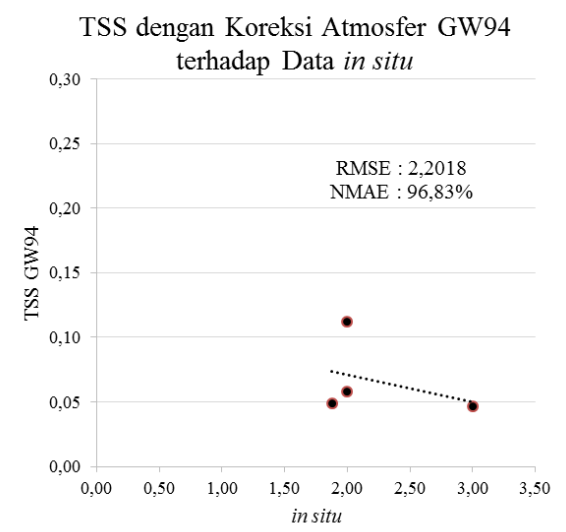

Gambar. 16. Grafik Korelasi antara TSS GW94 dengan Data In situ pada Citra Aqua MODIS. 


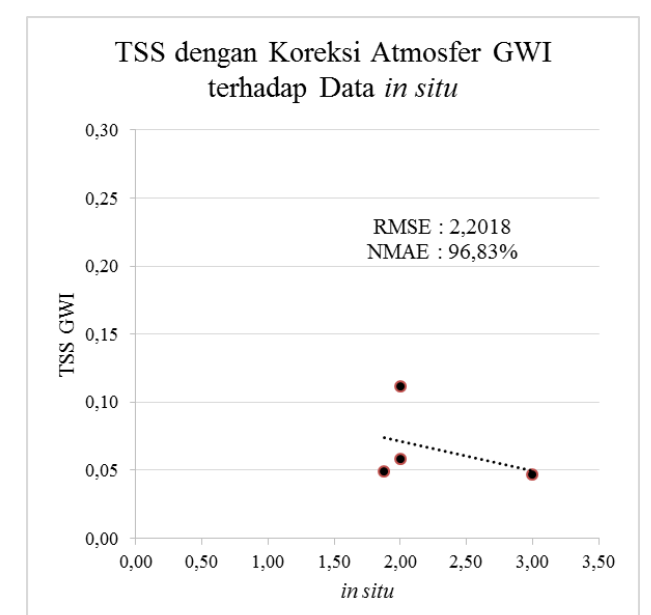

Gambar. 17. Grafik Korelasi antara TSS GWI dengan Data In situ pada Citra Aqua MODIS.

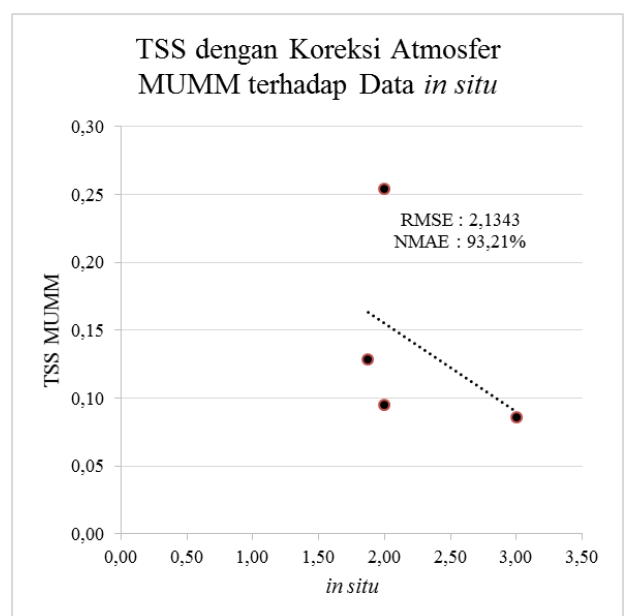

Gambar. 18. Grafik Korelasi antara TSS MUMM dengan Data in situ pada citra Aqua MODIS.

Berdasarkan nilai NMAE dari validasi ini menunjukkan bahwa koreksi atmosfer MUMM merupakan koreksi terbaik dalam mengestimasi TSS tetapi tidak dapat direkomendasikan karena nilai NMAE tidak memenuhi syarat minimal NMAE.

\section{KESIMPULAN DAN SARAN}

Kesimpulan dari penelitian ini adalah koreksi atmosfer terbaik dalam pendugaan klorofil-a dan TSS yaitu koreksi atmosfer MUMM. Berdasarkan hasil pemetaan klorofil-a dan TSS dihasilkan nilai NMAE sebesar $158,34 \%$ untuk klorofil-a. Sedangkan pemetaan TSS dihasilkan nilai NMAE sebesar $65,26 \%$. Hal ini menunjukkan bahwa algoritma empiris pada perangkat lunak SeaDAS 7.3.1 tersebut tidak memenuhi syarat akurasi minimal untuk diterapkan pada perairan Selat Makassar.

Sebaran klorofil-a pada citra Terra MODIS dengan 3 koreksi atmosfer yang berbeda memiliki nilai terendah sebesar 0,105 $\mu \mathrm{g} / \mathrm{l}$ dan tertinggi sebesar $0,783 \mu \mathrm{g} / \mathrm{l}$. Serta klorofil-a pada citra Aqua MODIS memiliki nilai terendah $0,163 \mu \mathrm{g} / \mathrm{l}$ dan tertinggi $0,308 \mu \mathrm{g} / \mathrm{l}$. Sedangkan sebaran TSS pada citra Terra MODIS memiliki nilai terendah sebesar $0,02 \mathrm{mg} / \mathrm{l}$ dan tertinggi sebesar $6,88 \mathrm{mg} / \mathrm{l}$. Begitu juga pada citra Aqua MODIS, sebaran nilai TSS terendah sebesar $0,05 \mathrm{mg} / \mathrm{l}$ dan tertinggi $0,25 \mathrm{mg} / \mathrm{l}$.

\section{UCAPAN TERIMA KASIH}

Penulis mengucapkan terima kasih kepada Pusat Penelitian Oseanografi - LIPI yang telah memberikan bantuan data EWIN 2013 sebagai data in situ di penelitian ini.

\section{DAFTAR PUSTAKA}

[1] M. Muswerry, "Kumpulan Hasil Penelitian Tahun 2013," Pusat Penelitian Oseanografi - LIPI, Jakarta, 2013.

[2] R. Effendi, P. Palloan and N. Ihsan, "Analisis Konsentrasi Klorofil-a di Perairan Sekitar Kota Makassar Menggunakan Data Satelit Topex/Poseidon," Jurnal Sains dan Pendidikan Fisika, pp. 279 - 285, 2012.

[3] J. Zhu, J. Chen, B. Matsushita and T. fukushima, "Atmospheric Correction of ENVISAT / MERIS Data Over Case II Waters: the use of black pixel assumption in oxygen and water vapour absorption bands," International Journal of Remote Sensing, pp. 3713 - 3732, 2012.

[4] L. M. Jaelani, B. Matsushita, w. Yang and T. fukushima, "An Improved Atmospheric Correction Algorithm for Applying MERIS Data to Very Turbid Inland Waters," International Journal of Applied Earth Observation and Geoinformation 39, pp. 128 -141, 2015.

[5] L. A. Karondia, Validasi Algoritma Estimasi Total Suspended Solid dan Klorofil-a pada Citra Satelit Aqua Modis dan Terra Modis Dengan Data Insitu, Surabaya: Jurusan Teknik Geomatika, 2015.

[6] A. Ocean Sciences Divisions, Processing of Oceansat-2 Ocean Colour Monitor Data Using SeaDAS, Hyderabad: Indian Space Research Organitation, 2012.

[7] L. M. Jaelani, F. Setiawan and B. Matsushita, "Uji Akurasi Produk Reflektan - Permukaan Landsat Menggunakan Data In Situ di Danau Kasumigaura, Jepang," Prosiding Pertemuan Ilmiah Tahunan Masyarakat Ahli Penginderaan Jauh Indonesia , 2015. 